\title{
Anterior Open Bite Using Simões Network in Growing Patient: A Case Report
}

\author{
Valquíria Fortunato Ribeiro, Critina Lúcia Feijó Ortolani, Taís Pereira Leal, Hatsuo Kubo and Carolina Bruder* \\ Department of Odontology, University of Paulista, Brazil
}

*Corresponding author: Carolina Bruder, Department of Odontology, University of Paulista, Brazil

Received: 眥 November 22, 2019

Published: 䐬 December 10, 2019

\begin{abstract}
The anterior open bite is characterized by the negative vertical overhang occurring in the anterior region. It consists of a discrepancy in the vertical direction and is one of the malocclusions with greater aesthetic-functional impairment, besides dental and skeletal alterations. It has a high prevalence in the deciduous and mixed dentition and its etiology is multifactorial, highlighting the deleterious oral habits as the most prevalent. The objective of this study was to present the clinical case of a growing female patient presenting an anterior open bite associated with thumb sucking, by means of treatment with the functional orthopedic device Simões Network (SN3). During the first 12 months follow-up, we observed facial and intraoral oral changes and forward, the improvement of functional and craniofacial relationships, observed through complementary tests.
\end{abstract}

Keywords: Open Bite; dentition, mixed; orthopedics

\section{Introduction}

The balance of soft tissue growth and facial changes are important for the craniofacial development. Mineralized bone is formed through a process known as ossification by the membrane activity providing the function of remodeling and displacement. Breath, chewing, phonation and swallowing functions are prior to the regular growth development [1]. Thumb or pacifier sucking, and tongue thrusting may cause a disorder knowing as an anterior open bite. The severity of the malocclusion will be according to the magnitude, frequency and time of the habit [2]. Prolonged breastfeeding will be recommended to avoid nonnutritive sucking habits, as the sucking of fingers, pacifiers and bottle feeding [3,4]. Anterior open bite (AOB) is defined as the lack of incisal contact between anterior teeth in centric relation. AOB creates aesthetics problems, speech disorders and tongue thrusting habit [5]. This malocclusion requires early treatment due to all the etiological factors mentioned before. The stability will be achieved in a long term; thus, the pediatric dentist must be alert and minimize the problem as soon as possible in attempt to decrease the time of the treatment and to maintain the stability 5 . The auto correction index is low when the correct habits are achieved [6,7]. The prevalence in the population ranges from $1,5 \%$ to $11 \%$. Some authors also describe that $17 \%$ to $36 \%$ of those seeking orthodontic treatments feature AOB [8-11]. This malocclusion may also occurs due to a skeletal component classified open bite into dental and skeletal, associated with excessive molar height, divergent upper and lower occlusal planes, steep mandibular plane angle, increased gonial angle, short mandibular ramus, downward rotation of posterior part of the maxilla or palatal plane tipped up anteriorly, increased lower anterior facial height and decreased upper anterior facial height. According to severity, modalities of treatment are required: growth modulation; orthodontic mechanotherapy and the combination with orthognathic surgery [12-14]. Orthopedics devices is a therapy to readapt the muscular system which is very efficient in growing patients resuming the facial balance [15]. This article presents a clinical case of growing female patient, with anterior open bite treated with the functional orthopedic device Simões Network (SN3) [16].

\section{Case Report}

A female patient, 8 years and 4 months of age, melanoderma, came for treatment at the Postgraduate Course in Orthodontics of Brazil University (São Paulo, SP, Brazil). A facial analysis detected convex facial profile, lack of lip closure, and a decrease in nasolabial angle (Figure 1). The patient exhibited thumb sucking habit, mixed breathing, atypical swallowing and speech. shows angle class II malocclusion, 6 millimeters of an anterior open bite, mild crowding and a supernumerary Figures $2 \& 3$ tooth in the anterior lower jaw with mandibular midline deviation to the right. Cephalometric Rx shows proclined upper incisors due to the thumb sucking the objetives 

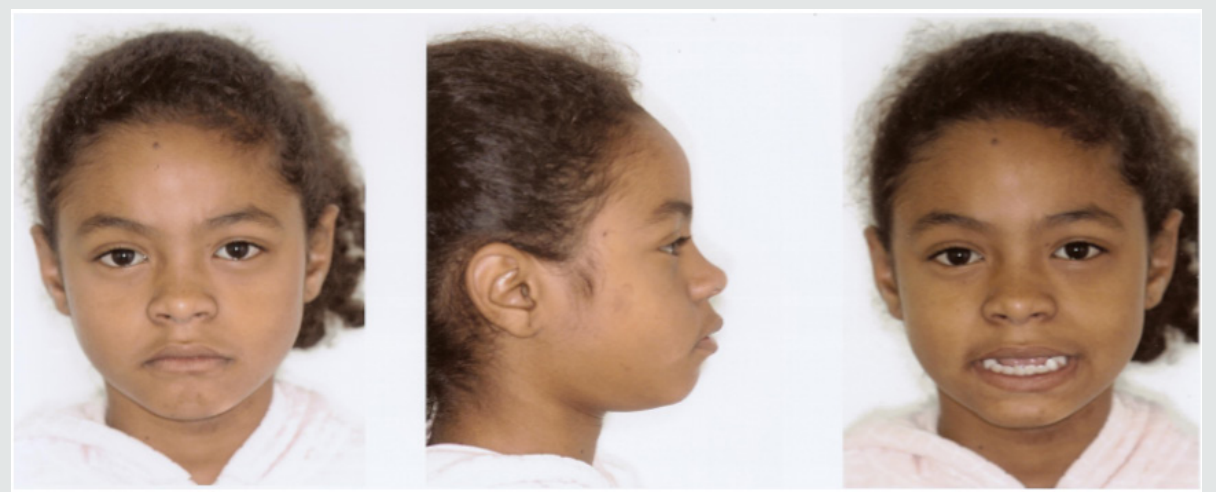

Figure 1: Convex facial profile, a decrease in nasolabial angle and the upper lip covering the incisor.
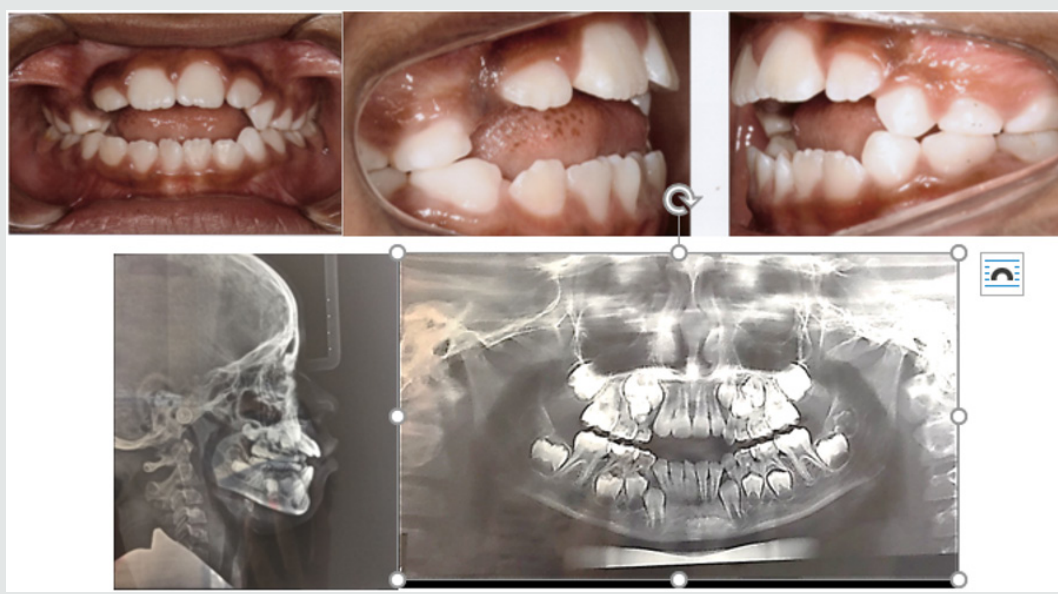

Figure 2: Anterior open bite, mild crowding and a supernumerary tooth in the anterior lower jaw and proclined upper incisors.

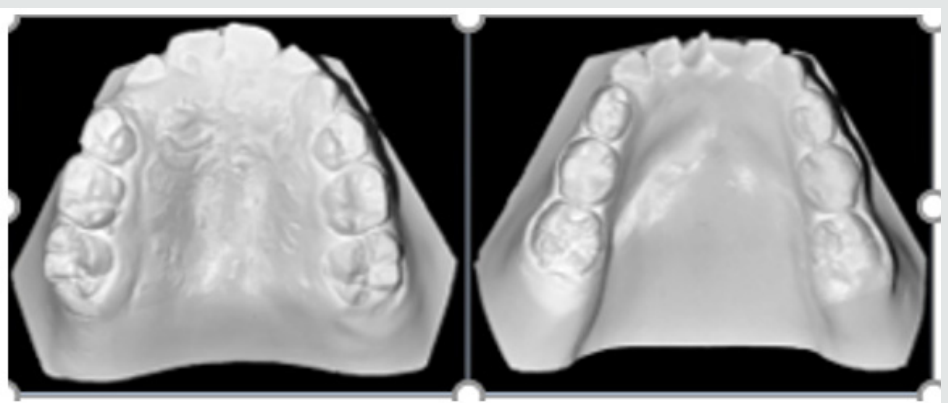

Figure 3: Angle class II malocclusion, supernumerary tooth in the anterior lower jaw and an $6 \mathrm{~mm}$ open bite.

for the first phase of the treatment were to eliminate the thumb sucking, the open bite, dental deviations, provide arch expansion and the extraction of the supernumerary tooth.

\section{Treatment Progress}

A removable appliance known by Simões Network (SN3) composed with a stainless steel bimaxillary grid ("lower winglets model") that simulates the incisors occlusion and provides the correct tongue position [15] (Figure 4). The screw was expanded with one-quarter turn biweekly. After 3 months of the treatment beginning o, we added a lip bumper to improve lip seal (Figure 5). We recommended the use for 10 or 12 hours a day. The supernumerary extraction was performed 7 months of the treatment beginning. Figure 6 shows the final of the first stage. Figure 7 shows Angle class I malocclusion and Figure 8 shows the Cephalometric and panoramic Rx after 23 months with the orthopedic appliance. Cephalometric superimposition (Figure 9) and analysis (Table 1) indicated dentoalveolar open bite pretreatment and the correction posttreatment. 

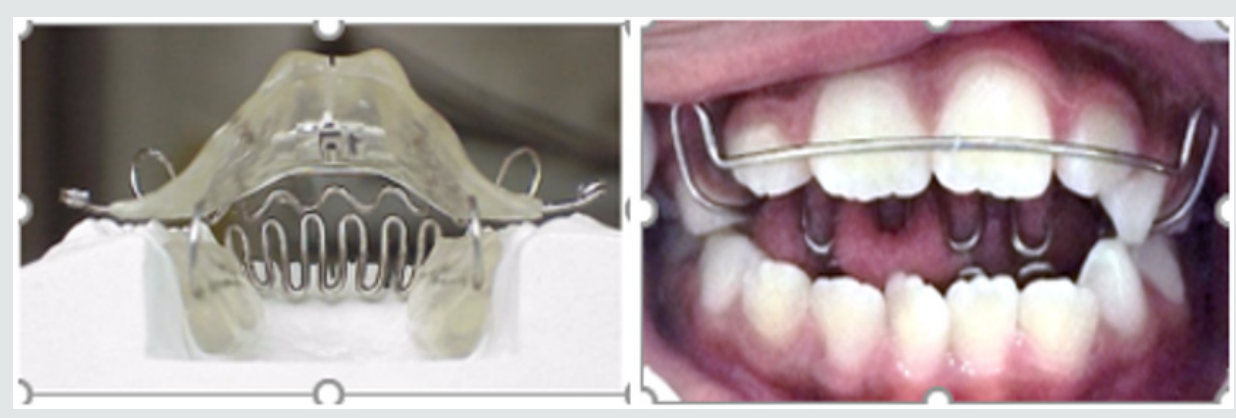

Figure 4: SN3 appliance, bimaxillary anchorage with "lower winglets model".

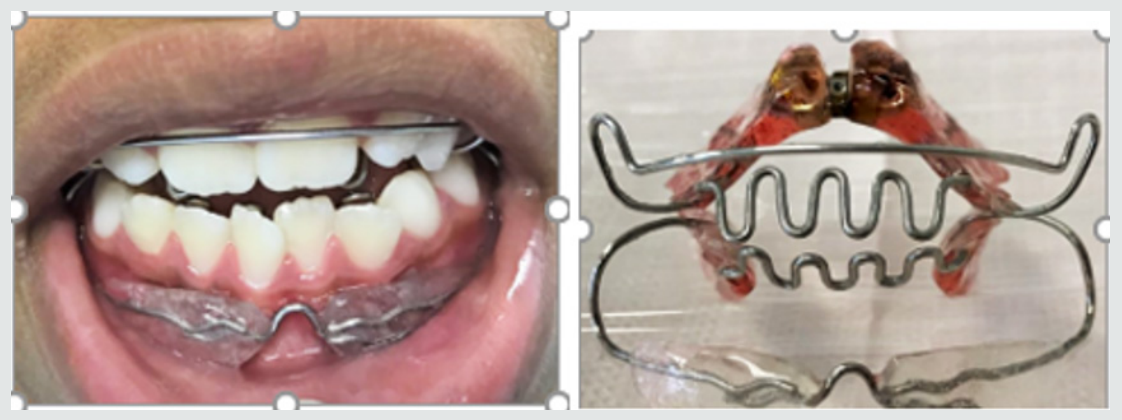

Figure 5: A lip bumper was added to improve lip seal.

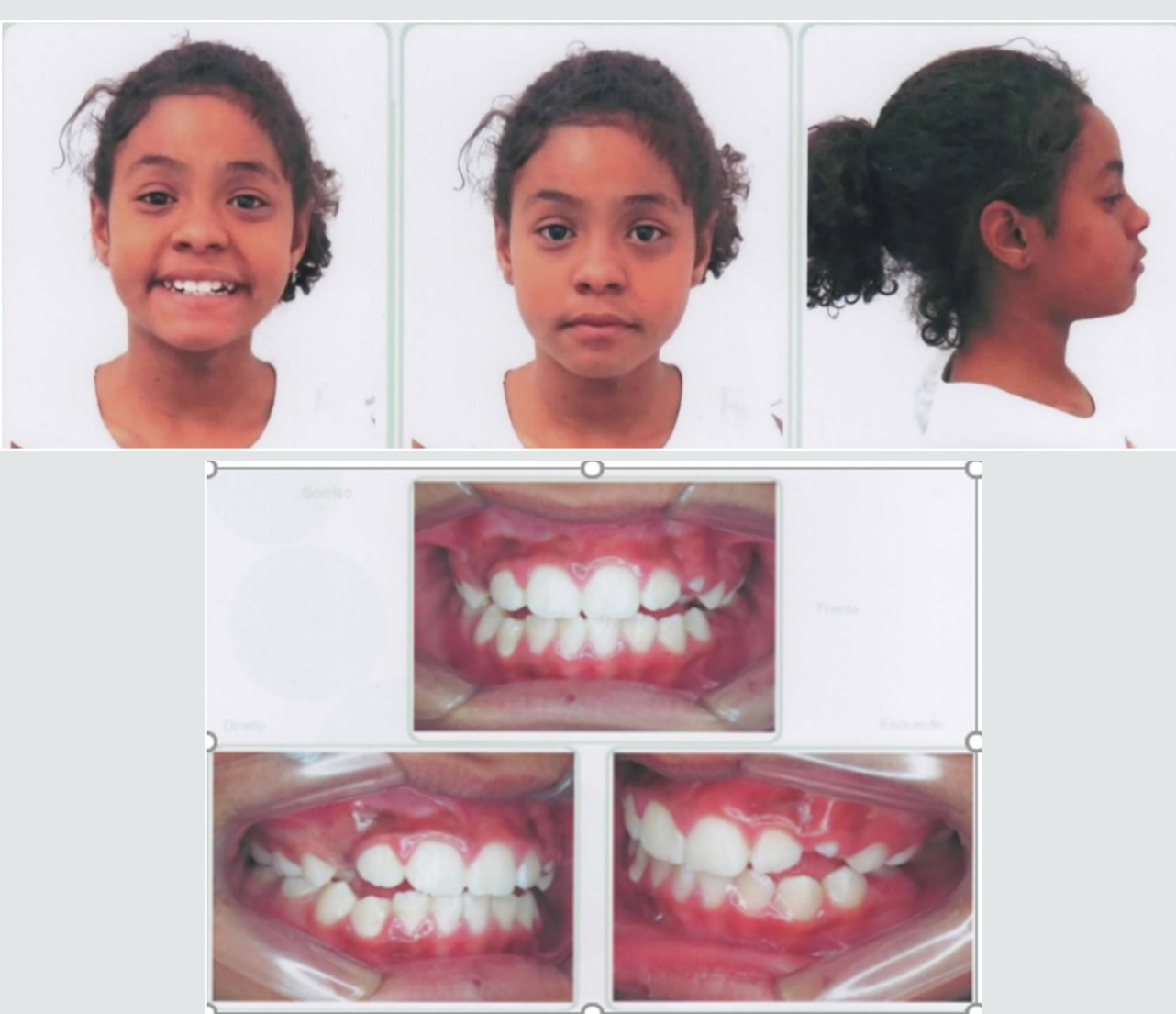

Figure 6: The correction of open bite and the improvement of the alignment. 


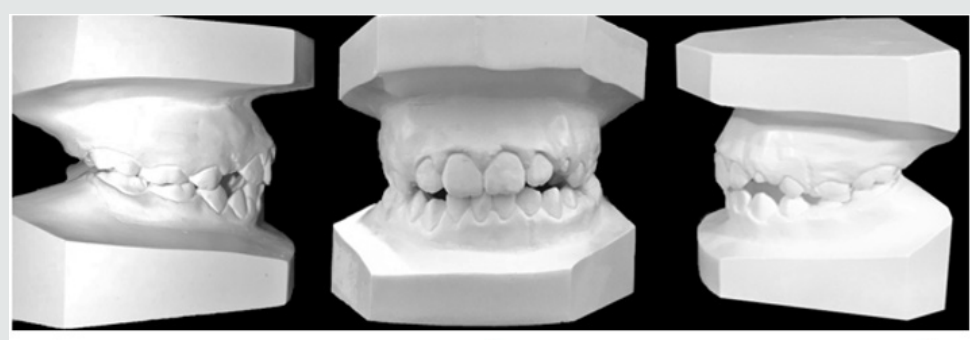

Figure 7: The arch expansion and molar Class I.
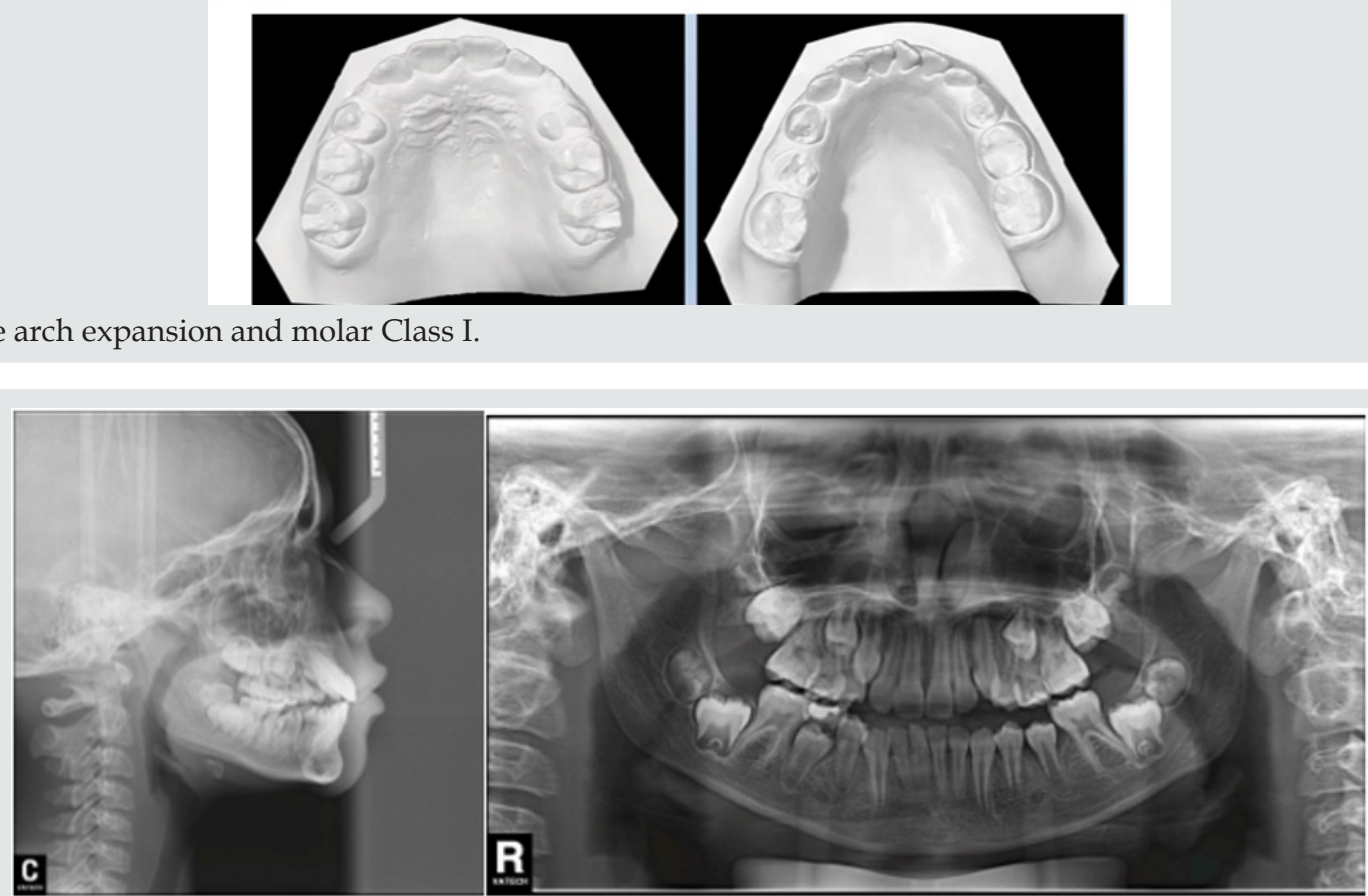

Figure 8: Cephalometric and panoramic Rx after 23 months of treatment.

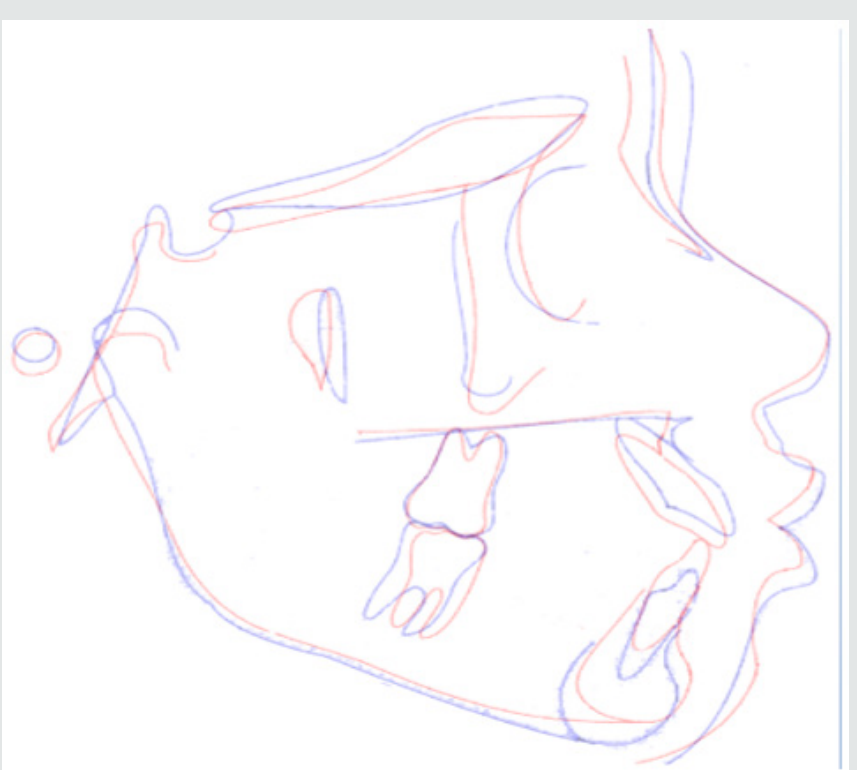

Figure 9: Cephalometric superimposition revealed maxillary incisor retrusion and mandibular incisor in normal bite. 
Table 1: Summary of cephalometric measures.

\begin{tabular}{|c|c|c|c|}
\hline Mesure & Norm & Pre & Post \\
\hline FMA & $25^{\circ}$ & $24.6^{\circ}$ & $22^{\circ}$ \\
\hline SN.Gn & $67^{\circ}$ & $65^{\circ}$ & $68^{\circ}$ \\
\hline ANB & $2^{\circ}$ & $2.42^{\circ}$ & $1,79^{\circ}$ \\
\hline SNA & $82^{\circ}$ & $83^{\circ}$ & $80^{\circ}$ \\
\hline SNB & $80^{\circ}$ & $81^{\circ}$ & $78^{\circ}$ \\
\hline $1 / . N A$ & $22^{\circ}$ & $33,4^{\circ}$ & $28^{\circ}$ \\
\hline $1 /-\mathrm{NA}$ & $4 \mathrm{~mm}$ & $5 \mathrm{~mm}$ & $5 \mathrm{~mm}$ \\
\hline $1 . \mathrm{NB}$ & $25^{\circ}$ & $29.3^{\circ}$ & $28^{\circ}$ \\
\hline $1 /-\mathrm{NB}$ & $4 \mathrm{~mm}$ & $4 \mathrm{~mm}$ & $5 \mathrm{~mm}$ \\
\hline
\end{tabular}

\section{Discussion and Conclusion}

According to the authors, AOB is a challenge daily faced because and it can result speech and swallows' problems, tongue posture and imbalance between jaw postures [17-19]. Bonna 2016 alerts that the orthodontics or orthopedic devices are fundamental but without family support the habit suppression will not be achieved [20]. The objective for the first phase of treatment were to eliminate thumb sucking, open bite and arch expansion with orthopedic appliance Simões Network SN3 and after a lip bumper was included to improve seal lip. These goals were achieved during the first stage. Graphic 1 shows best fit reduction open bite from May to November 2017. Even pubertal increments offer best time for orthopedic treatment helping determine the predictability, growth direction, patient management and total treatment time, we did not wait to treat because the disadvantages of the open bite [21]. This reported case was successfully treated with SN3 remained stable after the AOB correction. For the second phase with fixed orthodontic treatment will be necessary [22-29].

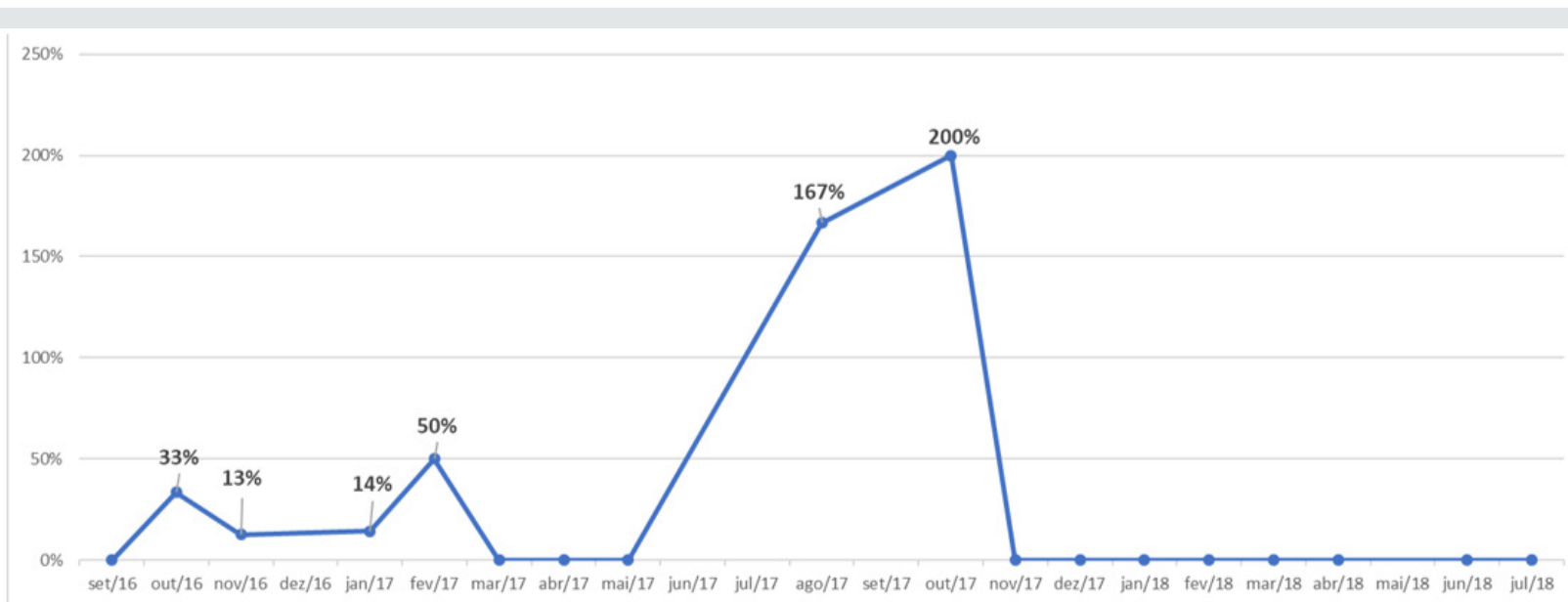

Graphic 1: Closure open bite variation during time.

\section{References}

1. Boeck EM, Pizzol KEDC, Navarro N, Chiozzini NM, Foschini ALR (2013) Prevalence of malocclusion in children between 5 and 12 years-old in municipal shools in Araraquara. Rev CEFAC 15: 1270-1280.

2. Bronzi ES, Minervino BL, Melo ACM, Santos Pinto A, Martins LP (2002) Mordida aberta em pacientes jovens. Relato clínico. Rev Fac Odontol Lins 14(1): 24-29.

3. Romero CC, Scavone Junior H, Garib DG, Cotrim Ferreira FA, Ferreira RI (2011) Breastfeeding and non-nutritive sucking patterns related to the prevalence of anterior open bite in primary dentition. J Appl Oral Scielo 19(2): 161-168.

4. Caglar E, Larsson E, Andersson EM, Hauge MS, Ogaard B, Bishara S, et al. (2005) Feeding, artificial sucking habits, and malocclusions in 3-yearold girls in different regions of the world. J Dent Child 72: 25-30.

5. Imparato JCP, Duarte DA, Manfro ARG (2012) Odontopediatria: Prática de saúde baseada em evidências. Elsevier, São Paulo, USA.

6. Proffit WR (1978) Equilibrium theory revisited: factors influencing position of the teeth. Angle Orthod 48: 175-186.

7. Almeida AB, Mazzieiro ÊT, Pereira TJ, Souki BQ, Viana CP (2002) Interceptação de uma mordida aberta esquelética associada à sucção digital: relato de um caso clínico. J Bras Ortodon Ortop Facial 7(42): 448454.
8. Frost HM (2004) A 2003 update of bone physiology and Wolff's Law for clinicians. The Angle Orthodontist 74(1): 3-15.

9. Petrovic A, Stutzmann J, Lavergne J, Shaye R (1990) Is it possible to modulate the growth of the human mandible with a functional appliance? International Journal of Orthodontics 29(1-2): 3-8.

10. Ramirez YGO, Farrell C (2005) Soft tissue dysfunction: a missing clue in orthodontics. International Journal Jaw Functional Orthopedics 1: 351359.

11. Smithpeter J, Covell D (2010) Relapse of anterior open bites treated with orthodontic appliances with and without orofacial myofunctional therapy. American Journal of Orthodontics and Dentofacial Orthopedics 137(5): 605-614.

12. Subtelny JD, Sakuda M (1964) Open bite: diagnosis and treat ment. American Journal of Orthodontics 50(5): 337-358.

13. Tosello DO, Vitti M, Berzin F (1999) EMG activity of the orbicularis oris and mentalis muscles in children with malocclusion, in competent lips and atypical swallowing - part II. Journal of Oral Rehabilitation 26(8): 644-649.

14. Usumez S, Uysal T, Sari Z, Basciftci FA, Karaman AI, Guray E (2004) The effects of early preorthodontic Trainer treatment on Class II, division 1 patients. The Angle Orthodontist 74(5): 605-609. 
15. Cozza P, Baccetti T, Franchi L, Mucedero M, Polimeni A (2005) Sucking habits and facial hyperdivergency as risk factors for anterior open bite in the mixed dentition. American Journal of Orthodontics and Dentofacial Orthopedics 128(4): 517-519.

16. Zuroff JP, Chen SH, Shapiro PA, Little RM, Joondeph DR, et al. (2010) Orthodontic treatment of anterior open-bite malocclusion: stability 10 years post retention. American Journal of Orthodontics and Dentofacial Orthopedics 137(3): 302-303.

17. Oliveira JM, Dutra AL, Pereira CM, Toledo OA (2011) Etiology and treatment of anterior open bite. Health Sci Inst J 29: 92-95.

18. Simoes WA (2004) Ortopedia Funcional de los Maxilares. Tercera edición. Artes Médicas Latinoamérica: São Paulo, USA.

19. Artese A, Drummond S, Nascimento JM, Artese F (2011) Critérios para o diagnóstico e tratamento estável da mor dida aberta anterior. Dental Press J Orthod 16(3):136-161.

20. Valencia AM, Hurtado AM, Hernández JA (2014) Tratamiento temprano de la mordida abierta anterior con aparatología ortopédica funcional. Reporte de caso Rev estomatol 22(2): 20-26.

21. Cozza P, Mucedero M, Baccetti T, Franchi L (2005) Early orthodontic treatment of skeletal open-bite malocclusion: A systematic review. Angle Orthod 75: 707-713.

22. Tiziano Baccetti, Lorenzo Franchi, James A McNamara (2002) An Improved Version of the Cervical Vertebral Maturation (CVM) Method for the Assessment of Mandibular Growth. Angle Orthod 72: 316-323.
23. American Board of Orthodontics (1990) Examination Information Manual. Apud Athanasiou, AE Op cit Ref 2.

24. Ricketts RM (1979) Bio progressive Therapy. Denver, Rocky Mountam Orthodontics, Colorado, USA.

25. Torres FC, Almeida RR, Almeida Pedrin RR, Pedrin F, Paranhos LR (2011) Dentoalveolar comparative study between removable and fixed cribs, associated to chincup, in anterior open bite treatment. J Appl Oral Sci 20(5): 531-537.

26. Pacheco AB, Da Silva AMT, Mezzomo CL, Berwig LC, Neu AP (2012) Relationship between mouth breathing and non-nutritive sucking habits with stomatognathic system alterations. Rev Cefac 14(2): 281-289.

27. Almeida RR (2013) Ortodontia preventiva e interceptora: Mito ou realidade? Maringá Dental Press.

28. Lindner A, Hellsing E (1991) Cheek and lip pressure against maxillary dental arch during dummy sucking. The European Journal of Orthodontics 13(5): 362-366.

29. Lowe AA, Takada K (1984) Associations between anterior temporal, masseter, and orbicularis oris muscle activity and cranio facial morphology in children. American Journal of Orthodontics 86(4): 319330.

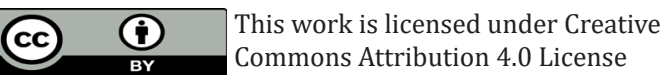

To Submit Your Article Click Here: Submit Article

DOI: $10.32474 /$ IPDOAJ.2019.03.000166

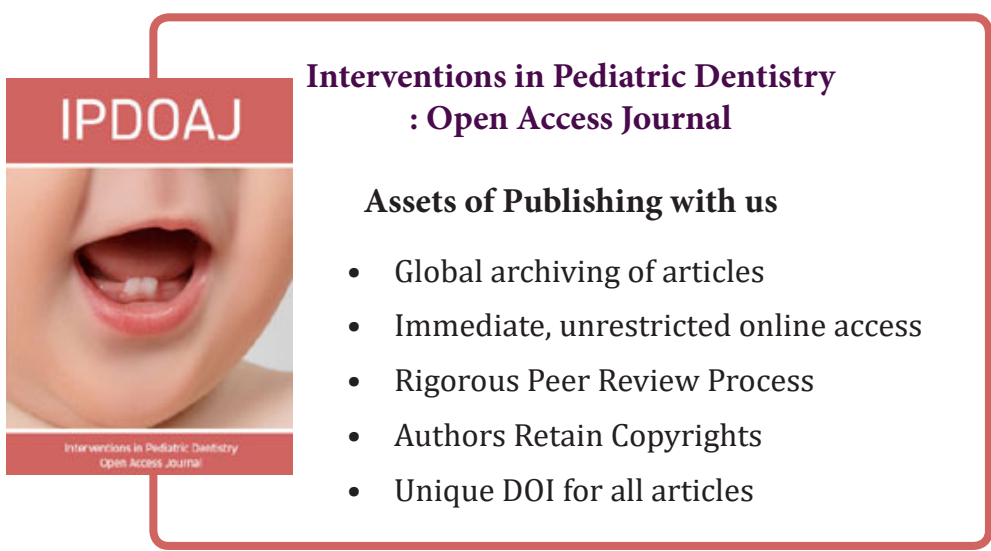

